\title{
RAD54B wt Allele
}

National Cancer Institute

\section{Source}

National Cancer Institute. RAD54B wt Allele. NCI Thesaurus. Code C49408.

Human RAD54B wild-type allele is located within 8q21.3-q22 and is approximately $103 \mathrm{~kb}$ in length. This allele, which encodes DNA repair and recombination protein RAD54B, plays a role in both mitotic recombination and DNA repair. Certain allelic variants of the RAD54B gene are associated with several types of cancer such as colon cancer and primary lymphoma. 